Scientia Agricola

http://dx.doi.org/10.1590/0103-9016-2014-0261

\title{
How can dairies maximize their profits and properly remunerate their dairy farmers?
}

\author{
Rafael Cedric Möller Meneghini ${ }^{*}$, Laerte Dagher Cassoli², João Gomes Martines Filho ${ }^{3}$, Carlos Eduardo Osório Xavier ${ }^{4}$, Marcos \\ Veiga dos Santos ${ }^{5}$, José Vicente Caixeta Filho ${ }^{3}$, Andressa Santanna Natel ${ }^{6}$, Paulo Fernando Machado ${ }^{2}$
}

\author{
${ }^{1}$ Federal Institute of Education, Science and Technology of \\ São Paulo, Av. Professor Celso Ferreira da Silva, 1333 - \\ 18707-150 - Avaré, SP - Brazil. \\ 2University of São Paulo/ESALQ - Dept of Animal Science, \\ Av. Pádua Dias, 11, C.P. 09 - 13418-900- Piracicaba, SP \\ - Brazil. \\ 3University of São Paulo/ESALQ - Dept of Economics, \\ Management and Sociology. \\ ${ }^{4}$ Federal University of São Carlos - Dept of Economics, Rod. \\ SP 264, km 110 - 18052-780 - Sorocaba, SP - Brazil. \\ EUniversity of São Paulo/FMVZ - Dept of Animal Production \\ and Nutrition, Av. Duque de Caxias, 225 - 13635-900 - \\ Pirassununga, SP - Brazil. \\ EUniversity of São Paulo/CENA - Division of Food and \\ Agroindustrial Production, Av. Centenário, 303, C.P. 96 - \\ 13416-000 - Piracicaba, SP - Brazil. \\ *Corresponding author <meneghini@ifsp.edu.br>
}

Edited by: Concepta Margaret McManus Pimentel

Received August 17, 2014

Accepted July 06, 2015
ABSTRACT: The current pricing process of raw milk in Brazil discourages producers from improving milk composition, which affects both yield and quality of dairy products. Furthermore, small and medium-sized dairies face great difficulties when it comes to planning production. Thus, a linear programming model was developed to price the raw milk and determine the optimal mix (combination of quantities) of dairy products that maximizes total contribution margin (TCM) under daily scenarios of high (January) and low (July) raw milk supplies (summer and winter, respectively) by comparing optimal solutions with actual results. The TCM of optimal and actual mixes were higher in January due to the greater availability of raw material. Packaging was a limiting factor in the production of cheese in optimal mixes. The relationship between unit contribution margin (UCM) and the required amount of raw materials per product unit and resource availability is crucial to defining the mix of dairy products and TCM of the dairy. Casein and raw milk volume showed shadow prices. Under both scenarios, the calculated prices of raw milk were higher than the prices charged by the dairy and were higher in January. The proposed model remunerates the producers based on the quantity and quality of raw milk. The dairy can maximize its TCM by better planning its mix of products with the use of linear programming.

Keywords: contribution margin, dairy products, linear programming, milk components, milk pricing

\section{Introduction}

Brazilian dairies face two very usual problems: one is related to the quality of its main raw material, milk, and the other to production planning of the mix (combination of quantities) of dairy products, such as cheeses, milk, cream, etc. for sale.

Raw milk quality affects industrial yield, milk processing, dairy product quality and profitability of producers and dairies (Blowey and Edmondson, 2010). A number of Brazilian dairies currently have in place compensation systems to producers with awards and penalties assigned to the liter price $(\mathrm{L})$ of raw milk based on quality criteria, such as Total Bacterial Count (TBC), Somatic Cell Count (SCC), protein and fat contents, as an incentive for milk quality improvement (Roma et al., 2009). However, these programs have not increased the protein and fat content of raw milk supplied to dairies (Botaro et al., 2013).

Programming the mix of dairy products that maximizes the total contribution margin (TCM), i.e. the difference between revenue and direct costs, is a major challenge faced by dairies, mainly small and mediumsized ones (Kerrigan and Norback, 1986). This challenge is attributed to milk production seasonality, milk quality variability, low qualification of staff in charge of dairy production planning, failures in production planning, lack of awareness of decision-support tools, the absence or adoption of rudimentary practices of accounting controls and the lack of familiarity with technical coefficients and indicators of industrial efficiency related to the use of equipment, structure, material and human resources of the dairy processing plant (Banaszewska et al., 2013).

Defining a more profitable mix becomes very difficult without support from mathematical and computational tools for decision making when planning the production of dairy products, since this task requires calculations that involve many technical and economic factors (Geary et al., 2010a). However, computer programs based on linear programming (LP) are available and can resolve the issues regarding the definition of the optimal mix to maximize the TCM in a simplified form which respects operational and market constraints. LP is a mathematical technique for solving systems of linear equations or inequations by inverting matrices, being a mathematical model used for more efficient allocation of resources (Dantzig, 1998; Sharma, 2006).

A model that supports strategic decisions and milk pricing strategies would be helpful in determining the mix of milk products and the characteristics of the raw milk supplied (Geary et al., 2010b). To fulfill these needs, we developed a mathematical model for smallsized dairies to price raw milk in terms of its quality and to maximize TCM through the definition of the optimal mix of products using LP. 


\section{Materials and methods}

A mathematical model was developed to maximize total contribution margin (TCM) of dairies and to determine the maximum price per liter (L) of raw milk supplied by dairy farmers. The model was developed and tested using technical and economic data from a small-sized dairy in the municipality of Piracicaba, in the state of São Paulo, Brazil. Technical and accounting coefficients were calculated as below.

The total contribution margin and maximum price per volume (L) of raw milk were calculated by definitions of the optimal mix (ideal combination of quantities) of dairy products ' $i$ ' and of the shadow price of the limiting components of raw milk under constraints in two daily scenarios, respectively. The shadow price can be interpreted as the marginal profit that would be obtained if another unit of the limiting resource were processed. Therefore, one can understand that the shadow price of the limiting resource is the maximum price that can be paid for such resource without making a loss.

The model was processed by means of the GAMS 24.0 computational program (General Algebraic Modeling System 24.0) using the Cplex solver version 12.5.0.0 (McCarl et al., 2013) under both scenarios (Figure 1).

Table 1 - Average volumes and contents of the components of two types of raw milk obtained by the dairy under daily scenarios of high (January) and low (July) raw milk supplies.

\begin{tabular}{|c|c|c|c|c|}
\hline \multirow{2}{*}{$\begin{array}{l}\text { Scenarios } \\
\text { Raw milk types }\end{array}$} & \multicolumn{2}{|c|}{$\begin{array}{l}\text { High raw milk } \\
\text { supply (January) }\end{array}$} & \multicolumn{2}{|c|}{$\begin{array}{l}\text { Low raw milk } \\
\text { supply (July) }\end{array}$} \\
\hline & Raw milk $1^{1}$ & Raw milk $50^{2}$ & Raw milk $1^{1}$ & Raw milk $50^{2}$ \\
\hline Volume, $\mathrm{L}^{3}$ & 1208.55 & 8206.51 & 1123.07 & 4172.03 \\
\hline Fat, \% & 3.27 & 3.12 & 3.79 & 3.54 \\
\hline Protein, \% & 3.28 & 3.19 & 3.41 & 3.29 \\
\hline Casein, \% & 2.56 & 2.50 & 2.65 & 2.53 \\
\hline
\end{tabular}

${ }^{1}$ Raw milk for the production of brand $X$ cooled pasteurized milk standardized at $3 \%$ of fat; ${ }^{2}$ Raw milk for the production of other dairy products and ${ }^{3} 1 \mathrm{~L}=$ $1 \mathrm{dm}^{3}=10^{-3} \mathrm{~m}^{3}$; Source: elaborated by the author based on data from the dairy and the Milk Clinic Lab.

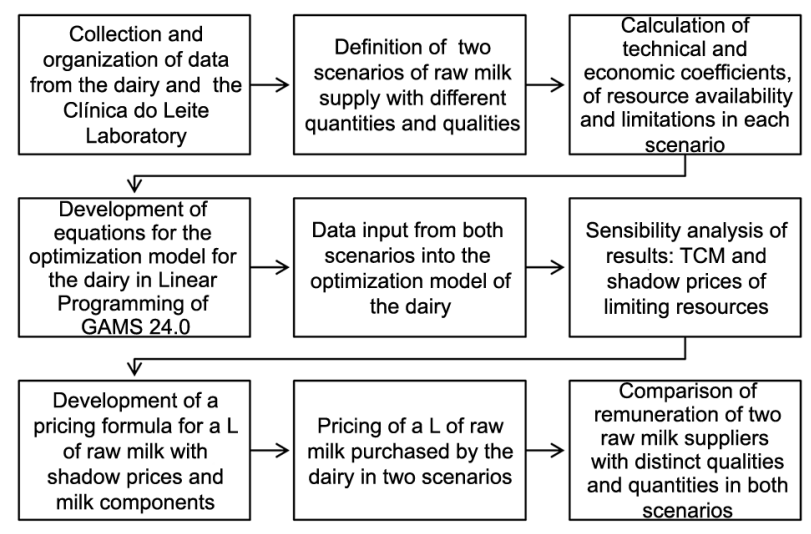

Figure 1 - Flowchart of summarized processes adopted in the research methodology.

\section{Scenarios}

We defined two daily scenarios we named ' $\mathrm{j}$ ' corresponding to the months of 2011 with high (January) and low (July) raw milk supplies (in liters) with different average compositions $(\%)$, simulating the peak (summer) and off-season (winter) periods of raw milk production, respectively (Table 1).

\section{Objective function}

The objective function of the model is to maximize the TCM of the dairy in each daily scenario ' $\mathrm{j}$ ' by adding the products of multiplications of decision variables (dairy products ' $i$ ') to the respective contribution margins per unit (UCM) (Equation 1).

$\mathrm{TCM}_{\mathrm{j}}=\sum_{i=1}^{10}(\mathrm{Xij} * \mathrm{UCMij}), \mathrm{j}=1,2$

where: $\mathrm{TCM}_{\mathrm{j}}=$ total contribution margin (US\$) of ' $\mathrm{j}$ ' scenario, $\mathrm{X}_{\mathrm{ij}}=$ quantity $(\mathrm{kg})$ or volume $(\mathrm{L})$ of the dairy product ' $\mathrm{i}$ ' in the ' $\mathrm{j}$ ' scenario and $\mathrm{UCM}_{\mathrm{ij}}=$ contribution margin per unit (US\$) of the dairy product ' $i$ ' in the ' $j$ ' scenario.

The contribution margin per unit is the difference between the selling price and the direct cost per unit of each dairy product. Raw milk costs were not included as direct costs in order to determine the shadow prices per volume (L) of raw milk or per mass $(\mathrm{kg})$ of its components. Interest, taxes, depreciation and amortization were also not considered. The selling prices of dairy products were fixed under both scenarios in order to evaluate the effect of differences in the quantity and quality of raw milk only on TCMs and shadow prices of the limiting resources of the dairy under both scenarios.

\section{Decision variables}

The 10 dairy products produced by the dairy denominated as ' $i$ ' consisted of two brands of milk (brand $\mathrm{X}$ cooled standardized pasteurized milk with $3 \%$ fat (XM) and brand $\mathrm{Y}$ - a cooled standardized pasteurized milk with $3 \%$ fat (YM)), milk cream with $40 \%$ fat (C40) from XM and YM standardization and seven kinds of cheese (Minas Standard (MS), Mozzarella Cheese (MC), Mozzarella Ball $(\mathrm{MB})$, Minas Fresh (MF), Provolone Ball (PB), Spicy Provolone (SP) and Ricotta Cheese (RC)). A single producer provided the raw milk (RM1) for XM production daily while approximately 50 producers supplied raw milk (RM50) for processing the other dairy products. The milk cream was sold to other food mills while the other nine dairy products were sold to retail customers from neighboring counties (bakeries, grocery stores and small markets).

\section{Restrictions and equations}

The maximization of the dairy's TCM was subject to technical, market and resources constraints in both scenarios. We calculated daily average quantities (kg) available in fat, protein and casein according to daily average volumes $(\mathrm{L})$ and contents $(\%)$ of daily components of RM1 and RM50 types of raw milk (Table 2), according to the following equations: 
$\mathrm{P}_{\mathrm{RMj}}=\mathrm{V}_{\mathrm{RMj}} * \% \mathrm{P}_{\mathrm{RMj}} * 1.03 / 100$;

$\mathrm{C}_{\mathrm{RMj}}=\mathrm{V}_{\mathrm{RMj}} * \% \mathrm{C}_{\mathrm{RMj}} * 1.03 / 100$;

$\mathrm{F}_{\mathrm{RMj}}=\mathrm{V}_{\mathrm{RMj}} * \% \mathrm{~F}_{\mathrm{RMj}} * 1.03 / 100$ and

where $\mathrm{P}_{\mathrm{RMj}}=$ quantity $(\mathrm{kg})$ of raw milk protein in the ${ }^{\prime} \mathrm{j}$ ' scenario, $\mathrm{V}_{\mathrm{RMj}}=$ average volume $(\mathrm{L})$ of raw milk collected in scenario ' $j$ ', $\% \mathrm{P}_{\mathrm{RMj}}=$ average protein content $(\%)$ of raw milk in the ' $\mathrm{j}$ ' scenario, 1.03 = average density of raw milk $\left(\mathrm{kg} \mathrm{L}^{-1}\right), \mathrm{C}_{\mathrm{RM}} \mathrm{j}=$ quantity $(\mathrm{kg})$ of raw milk casein in the ' $\mathrm{j}$ ' scenario, $\% \mathrm{C}_{\mathrm{RMj}}=$ average casein content $(\%)$ of raw milk in the ' $\mathrm{j}$ ' scenario, $\mathrm{F}_{\mathrm{RMj}}=$ quantity (kg) of raw milk fat in the ' $j$ ' scenario and $\% \mathrm{~F}_{\mathrm{RMj}}=$ average fat content $(\%)$ of raw milk in the ' $j$ ' scenario.

The whey volume generated in production of each type of cheese ' $i$ ' was determined under both scenarios ' $\mathrm{j}$ ' by the following equation:

$\mathrm{V}_{\mathrm{WHQij}}=\left(1.03 * \mathrm{~V}_{\mathrm{RM} 50 \mathrm{Q} i \mathrm{j}} * \mathrm{Q}_{\mathrm{ij}}-\mathrm{Q}_{\mathrm{ij}}\right) / 1.025$

where: $\mathrm{V}_{\text {wHOij }}=$ whey volume (L) generated per quantity $(\mathrm{kg})$ of cheese ' $\mathrm{i}$ ' produced in the ' $\mathrm{j}$ ' scenario, $1.03=$ average density $\left(\mathrm{kg} \mathrm{L}^{-1}\right)$ of raw milk, $\mathrm{V}_{\mathrm{RM} 50 \mathrm{Oij}}=$ volume (L) of RM50 required per $\mathrm{kg}$ of cheese ' $\mathrm{i}$ ' $\left(\mathrm{L} \mathrm{kg}^{-1}\right)$ in the ' $\mathrm{j}$ ' scenario, $\mathrm{Q}_{\mathrm{ij}}=$ quantity $(\mathrm{kg})$ of cheese ' $\mathrm{i}$ ' produced in the ' $\mathrm{j}$ ' scenario and $1.025=$ average density $\left(\mathrm{kg} \mathrm{L}^{-1}\right)$ of whey. The sum of $\mathrm{V}_{\text {wHOij }}$ corresponds to the total volume (L) of whey from cheeses 'i' available for ricotta production under the ' $\mathrm{j}$ ' scenario.

The quantities $(\mathrm{kg})$ available of fat and whey protein were calculated according to volumes (L) and average compositions $(\%)$ of whey (Teixeira and Fonseca, 2008), according to the following equations:

$\mathrm{KP}_{\mathrm{Sj}}=\Sigma \mathrm{V}_{\text {WHQij }} * 0.82 * 1.025 / 100$;

$\mathrm{KF}_{\mathrm{Sj}}=\Sigma \mathrm{V}_{\text {WHQij }} * 0.725 * 1.025 / 100$ and

where: $\mathrm{KP}_{\mathrm{Sj}}=$ mass $(\mathrm{kg})$ of whey protein under the ' $\mathrm{j}$ ' scenario, $\Sigma \mathrm{V}_{\text {wHoij }}=$ sum of whey volumes (L) in cheese production ' $i$ ' in the ' $j$ ' scenario, $0.82=$ average content $(\%)$ of whey protein, $1.025=$ average density $\left(\mathrm{kg} \mathrm{L}^{-1}\right)$ of whey, $\mathrm{KF}_{\mathrm{Sj}}=$ fat quantity $(\mathrm{kg})$ in whey under the $\mathrm{j}^{\mathrm{j}}$ scenario and $0.725=$ average fat content $(\%)$ in whey.

Beyond the restrictions of raw materials in Table 2 (milk components), the optimal solution of the mix of dairy products to maximize the TCM should respect the restrictions of daily demand from retail customers for dairy products (Table 3), equipment capacities and available working hours of the labor force.

The dairy sold its products to other food mills and retail customers from neighboring counties (bakeries, grocery stores and small markets). In both scenarios, the dairy had to meet the minimum demands but operate within the maximum sales limit of their products. Minimum demand $\left(\mathrm{D}_{\text {Min }}\right)$ for dairy $\mathrm{XM}, \mathrm{YM}$ and $\mathrm{MC}$ corresponded to orders and contractual requirements of customers, while the minimum demands of other dairy products were due to the strategy of positioning and maintenance of the company's brand in the market. Maximum demand $\left(\mathrm{D}_{\mathrm{Max}}\right)$ for dairy products corresponded to the maximum sales recorded in both January and July. The demand for each product was represented by an interval based on a quantity representative of the dairy plant's sales. This option to represent demand brings flexibility to the model proposed for calculating the best production mix designed to maximize the TCM of the dairy given its likely actual demand reality. Every dairy product produced was considered to have been sold as there were no records of returns of products not sold by retailers to end of chain consumers in either January or July. The restriction imposed on demand is represented by the following mathematical expression:

$\mathrm{D}_{\text {MinXij }} \leq \sum_{\mathrm{i}=1}^{10} \mathrm{Xij} \leq \mathrm{D}_{\text {MaxXij }} \mathrm{j}=1,2$

where: $\mathrm{D}_{\text {MinXij }}=$ minimum demand for dairy product ' $\mathrm{i}$ ' under the ' $\mathrm{j}$ ' scenario, $\sum_{\mathrm{i}=1}^{10} \mathrm{Xij}=$ sum of quantity $(\mathrm{kg})$ or

Table 2 - Average constraints of volume and components of two types of raw milk obtained by the dairy in daily scenarios of high (January) and low (July) raw milk supplies.

\begin{tabular}{|c|c|c|c|c|}
\hline \multirow{2}{*}{$\begin{array}{l}\text { Scenarios } \\
\text { Raw milk types }\end{array}$} & \multicolumn{2}{|c|}{$\begin{array}{l}\text { High raw milk } \\
\text { supply (January) }\end{array}$} & \multicolumn{2}{|c|}{$\begin{array}{l}\text { Low raw milk } \\
\text { supply (July) }\end{array}$} \\
\hline & Raw milk $1^{1}$ & Raw milk $50^{2}$ & Raw milk $1^{1}$ & Raw milk $50^{2}$ \\
\hline Volume, L $^{3}$ & 1208.55 & 8206.51 & 1123.07 & 4172.03 \\
\hline Fat, kg & 40.71 & 263.42 & 43.84 & 152.17 \\
\hline rotein, $\mathrm{kg}$ & 40.83 & 269.87 & 39.45 & 141.50 \\
\hline asein, kg & 31.87 & 211.40 & 30.65 & 108.56 \\
\hline
\end{tabular}

${ }^{1}$ Raw milk for the production of brand $X$ cooled pasteurized milk standardized at $3 \%$ of fat; ${ }^{2}$ Raw milk for the production of other dairy products and ${ }^{3} 1 \mathrm{~L}=$ $1 \mathrm{dm}^{3}=10^{-3} \mathrm{~m}^{3}$; Source: elaborated by the author based on data from the dairy and the Milk Clinic Lab.

Table 3 - Maximum and minimum demands of each dairy product produced by the dairy in daily scenarios of high (January) and low (July) raw milk supplies.

\begin{tabular}{lcccccc}
\hline Scenarios & \multicolumn{2}{c}{$\begin{array}{c}\text { High raw milk } \\
\text { supply (January) }\end{array}$} & & \multicolumn{2}{c}{$\begin{array}{c}\text { Low raw milk } \\
\text { supply (July) }\end{array}$} \\
\cline { 1 - 3 } \cline { 5 - 6 } Demands & Minimum & Maximum & & Minimum & Maximum \\
\hline XM, L1 & 180 & 1389 & & 180 & 1101 \\
YM, L ${ }^{1}$ & 240 & 6269 & & 240 & 2721 \\
MS, kg & 1 & 24 & & 1 & 24 \\
MC, kg & 127 & 1278 & & 127 & 167 \\
MB, kg & 1 & 10 & & 1 & 10 \\
MF, kg & 73 & 524 & & 36 & 281 \\
PB, kg & 6 & 209 & & 1 & 31 \\
SP, kg & 6 & 209 & & 1 & 20 \\
RC, kg & 5 & 70 & & 10 & 75
\end{tabular}

$\mathrm{XM}=$ brand $\mathrm{X}$ cooled standardized pasteurized milk; $\mathrm{YM}=$ brand $\mathrm{Y}$ cooled standardized pasteurized milk; $M S=$ Minas Standard cheese; $M C=$ Mozzarella Common cheese; MB = Mozzarella Ball cheese; MF = Minas Fresh cheese; PB $=$ Provolone Ball cheese; SP = Spicy Provolone cheese; $\mathrm{RC}=$ Ricotta cheese and ${ }^{1} 1 \mathrm{~L}=1 \mathrm{dm}^{3}=10^{-3} \mathrm{~m}^{3}$; Source: elaborated by the author based on data from the dairy and Clinic of Milk Lab. 
volume (L) of the dairy product ' $\mathrm{i}$ ' under the ' $\mathrm{j}$ ' scenario and $\mathrm{D}_{\text {MaxXij }}=$ maximum demand for dairy product ' $\mathrm{i}$ ' under the ' $\mathrm{j}$ ' scenario.

The dairy had six employees working directly on the production line. Each one worked 6.29 h daily $(44$ $\mathrm{h}$ per week) totaling 37.71 daily man-hours. The time available for daily use of each equipment corresponded to a workday of 6.29 hours.

For each unit of dairy product, we calculated the respective technical and economic factors: raw milk and whey volumes in L, amounts of protein, casein and milk fat in $\mathrm{kg}$, amounts of protein and fat in whey in $\mathrm{kg}$, length of time equipment in use (pasteurizer, standardizer, pasteurized milk bagging and cheese packaging). We also calculated labor in hours (h), direct costs, UCM and indirect costs (Table 4). The unit contribution margin of $\mathrm{C} 40$ was US $\$ 1.19$. The unit contribution margins of each dairy product were the same under both scenarios since their selling prices and direct costs were considered constant.

Standardization of the technical coefficient, bagging, packaging, pasteurization, labor and the requirements of protein, casein and fat of both raw milk types as well as protein and fat from whey per unit of dairy product ' $i$ ' in both scenarios ' $j$ ' were calculated on the basis of the volumes of the two types of raw milk and whey that were necessary for unit production in L or kg for each dairy product ' $i$ '. Milk processing flows in pasteurization, standardization and packaging corresponded to 4500,6250 and $2500 \mathrm{~L} \mathrm{~h}^{-1}$, respectively. The packagers wrapped each cheese ' $i$ ' in 1.5 minutes. The labor time used for dairy product ' $i$ ' was calculated in terms of time required by equipment used and for product preparation. The volume of each raw milk type required for each L or kg of dairy product 'i' differs between the scenarios due to the difference in the composition of both raw milk types from each scenario.
The raw milk volume required and the amount of C40 generated per L of XM and YM were determined through the Subtractive Pearson Square method (Anderson et al., 1993):

$\mathrm{Q}_{\mathrm{C} 40 \mathrm{Xj}}=1.03 * \mathrm{~V}_{\mathrm{XMj}} *\left[(40-3)-\left(40-\mathrm{F}_{1 \mathrm{j}}\right)\right] /\left(40-\mathrm{F}_{1 \mathrm{j}}\right) ;$

$\mathrm{V}_{\mathrm{RM} 1 \mathrm{j}}=(40-3) /\left(40-\mathrm{F}_{1 \mathrm{j}}\right)$;

$Q_{\mathrm{C} 40 \mathrm{Yj}}=1.03 * \mathrm{~V}_{\mathrm{YMj}} *\left[(40-3)-\left(40-\mathrm{F}_{50 \mathrm{j}}\right)\right] /\left(40-\mathrm{F}_{50 \mathrm{j}}\right)$ and

$\mathrm{V}_{\text {RM50j }}=(40-3) /\left(40-\mathrm{F}_{50 \mathrm{j}}\right)$

where: $Q_{C 40 X j}=$ quantity $(\mathrm{kg})$ of cream $40 \%$ fat generated by the standardization of brand X cooled standardized pasteurized milk under scenario ' $\mathrm{j}$ ', 1.03 = average density $\left(\mathrm{kg} \mathrm{L}^{-1}\right)$ raw milk, $\mathrm{V}_{\mathrm{XMj}}=$ volume $(\mathrm{L})$ brand $\mathrm{X}$ cooled standardized pasteurized milk under the optimal mix of scenario ' $\mathrm{j}$ ', $40=$ average content $(\%)$ of fat in cream, 3 $=$ average fat content $(\%)$ of brand $\mathrm{X}$ cooled standardized pasteurized milk $(\%), \mathrm{F}_{1 \mathrm{j}}=$ fat content $(\%)$ in the RM1 under scenario ' $\mathrm{j}$ ' $(\%), \mathrm{V}_{\mathrm{RM} 1 \mathrm{j}}=$ volume (L) of RM1 required to process one L of brand X cooled standardized pasteurized milk, $F_{50 j}=$ fat content $(\%)$ in the RM50 under scenario 'j' (\%), $\stackrel{\mathrm{Q}}{\mathrm{C} 40 \mathrm{Yj}}=$ quantity $(\mathrm{kg})$ of cream $40 \%$ fat generated by the standardization of the brand Y cooled standardized pasteurized milk scenario ' $\mathrm{j}$ ', $\mathrm{V}_{\mathrm{YMj}}=$ volume $(\mathrm{L})$ brand $\mathrm{Y}$ cooled standardized pasteurized milk in the optimal mix of scenario ' $\mathrm{j}$ ' and $\mathrm{V}_{\mathrm{RM} 50 \mathrm{j}}=$ volume (L) RM50 required to process one $\mathrm{L}$ of brand $\mathrm{Y}$ cooled standardized pasteurized milk. The sum of $Q_{\mathrm{C} 40 \mathrm{Xj}}$ and $\mathrm{Q}_{\mathrm{C} 40 \mathrm{Yj}}$ corresponds to the total amount $(\mathrm{kg})$ of cream $40 \%$ fat generated by standardization of both brands of cooled standardized pasteurized milk under scenario ' $\mathrm{j}$ '.

To determine the milk volume required to produce each $\mathrm{kg}$ of $\mathrm{MS}, \mathrm{MC}, \mathrm{MB}, \mathrm{MF}, \mathrm{PB}, \mathrm{SP}$ and $\mathrm{RC}$ cheeses, we used the prediction equation for cheese production of Van Slyke adapted (Emmons and Modler, 2010; Melilli et al., 2002) as follows:

Table 4 - Coefficients of resources used per unit of dairy product in daily scenarios of high (January) and low (July) raw milk supplies.

\begin{tabular}{|c|c|c|c|c|c|c|c|c|c|}
\hline \multirow{2}{*}{ Resources $^{1}$} & \multicolumn{9}{|c|}{ High raw milk supply (January) } \\
\hline & $\mathrm{XM}$ & $\mathrm{YM}$ & MS & MC & $\mathrm{MB}$ & MF & PB & $\mathrm{SP}$ & $\mathrm{RC}$ \\
\hline Raw milk, $L^{2}$ & 1.01 & 1.00 & 8.12 & 8.91 & 8.91 & 6.13 & 11.43 & 11.43 & 3.91 \\
\hline Protein, kg & 0.034 & 0.033 & 0.267 & 0.293 & 0.293 & 0.202 & 0.376 & 0.376 & 0.129 \\
\hline Casein, kg & 0.027 & 0.026 & 0.209 & 0.230 & 0.230 & 0.158 & 0.295 & 0.295 & 0.101 \\
\hline Fat, kg & 0.030 & 0.030 & 0.261 & 0.286 & 0.286 & 0.197 & 0.367 & 0.367 & 0.126 \\
\hline Whey, $L^{2}$ & - & - & - & - & - & - & - & - & 16.03 \\
\hline Protein, kg & - & - & - & - & - & - & - & - & 0.135 \\
\hline Fat, kg & - & - & - & - & - & - & - & - & 0.119 \\
\hline Pasteurizer, h & 0.0002 & 0.0002 & 0.0018 & 0.0020 & 0.0020 & 0.0014 & 0.0025 & 0.0025 & 0.0009 \\
\hline Standardizer, h & 0.0002 & 0.0002 & - & - & - & - & - & - & - \\
\hline Bagging, $h$ & 0.0004 & 0.0004 & - & - & - & - & - & - & - \\
\hline Packager, h & - & - & 0.025 & 0.025 & 0.025 & 0.025 & 0.025 & 0.025 & 0.025 \\
\hline Labor, h & 0.0008 & 0.0008 & 0.0340 & 0.1130 & 0.1130 & 0.0290 & 0.1140 & 0.1140 & 0.0310 \\
\hline $\mathrm{UCM}^{3}, \mathrm{US}^{4}$ & 0.93 & 0.87 & 6.44 & 5.41 & 7.18 & 5.46 & 7.64 & 7.98 & 2.43 \\
\hline
\end{tabular}

${ }^{1} \mathrm{XM}=$ brand X cooled standardized pasteurized milk; YM = brand Y cooled standardized pasteurized milk; MS = Minas Standard cheese; MC = Mozzarella Common cheese; MB = Mozzarella Ball cheese; MF = Minas Fresh cheese; PB = Provolone Ball cheese; $\mathrm{SP}=$ Spicy Provolone cheese and RC = Ricotta cheese; ${ }^{2} 1 \mathrm{~L}=1 \mathrm{dm}{ }^{3}$ $=10^{-3} \mathrm{m3}$; ${ }^{3}$ Unit Contribution Margin and ${ }^{4} \mathrm{US} \$ 1.000$ = R\$ 1.675 (Brazil, 2013); Source: elaborated by the author based on data from the dairy and Clinic of Milk Lab. 
$\mathrm{V}_{\mathrm{RM} 50 \mathrm{Qij}}=1 /\left\{1.03 * 1.22 *\left[\left(\mathrm{RF}_{\mathrm{i}}^{*} \mathrm{~F}_{50 \mathrm{j}}\right)+\left(\mathrm{C}_{50 \mathrm{j}}-\mathrm{LC}_{\mathrm{i}}\right)\right] /\left(100-\mathrm{W}_{\mathrm{i}}\right)\right\}$

where: $\mathrm{V}_{\mathrm{RM} 50 \mathrm{Qij}}=$ volume $(\mathrm{L})$ of RM50 required for one $\mathrm{kg}$ of cheese ' $\mathrm{i}$ ' under the ' $\mathrm{j}$ ' scenario, $1.03=$ average density $\left(\mathrm{kg} \mathrm{L}^{-1}\right)$ raw milk, 1.22 = constant for adding salt and allowed solid, $\mathrm{RF}_{\mathrm{i}}=$ coefficient of milk fat retention in the cheese ' $\mathrm{i}$ ', $\mathrm{F}_{50 \mathrm{j}}=$ average fat content $(\%)$ in raw milk in scenario ' $\mathrm{j}$ ', $\mathrm{C}_{50 \mathrm{j}}=$ average casein content $(\%)$ in raw milk under the ' $\mathrm{j}$ ' scenario, $\mathrm{LC}_{\mathrm{i}}=$ loss $(\%)$ of milk casein in cheese production ' $\mathrm{i}$ ' and $\mathrm{W}_{\mathrm{i}}=$ average moisture content $(\%)$ of cheese ' $i$ '.

$\mathrm{RC}$ cheese is produced with pasteurized milk and whey resulting from the production of other cheeses. For volume calculation (L) of raw milk necessary to process one $\mathrm{kg}$ of $\mathrm{RC}$, we also used an adaptation of Van Slyke's formula (Emmons and Modler, 2010; Melilli et al., 2002) replacing the term ' $\mathrm{C}_{50 j}-\mathrm{LC}_{\mathrm{i}}$ ' by ' $\mathrm{RP}_{\mathrm{i}}{ }^{*} \mathrm{P}_{50 \mathrm{j}}$ ' as shown below:

$\mathrm{V}_{\mathrm{RM} 50 \mathrm{Oij}}=1 /\left\{1.03 * 1.22 *\left[\left(\mathrm{RF}_{\mathrm{i}} * \mathrm{~F}_{50 \mathrm{j}}\right)+\left(\mathrm{RP}_{\mathrm{i}} * \mathrm{P}_{50 \mathrm{j}}\right)\right] /\left(100-\mathrm{W}_{\mathrm{i}}\right)\right\}$

where: $\mathrm{RP}_{\mathrm{i}}=$ retention coefficient of protein in ricotta and $\mathrm{P}_{50 \mathrm{j}}=$ average content $(\%)$ of protein in raw milk in scenario ' $\mathrm{j}$ '.

The whey volume $(\mathrm{L})$ required to produce one $\mathrm{kg}$ of $\mathrm{RC}$ was defined by the following equation:

$\mathrm{V}_{\mathrm{WHj}}=1 /\left\{1.025 * 1.22 *\left[\left(\mathrm{RF}_{\mathrm{i}}^{*} 0.725\right)+\left(\mathrm{RP}_{\mathrm{i}}^{*} 0.82\right)\right] /(100-69.6)\right\}$

where: $\mathrm{V}_{\mathrm{wHj}}=$ whey volume $(\mathrm{L})$ required for one $\mathrm{kg}$ of ricotta under scenario ' $\mathrm{j}$ ', $1.025=$ average density $(\mathrm{kg}$ $\left.\mathrm{L}^{-1}\right)$ in whey, $1.22=$ constant for adding salt and allowed solid, $\mathrm{RF}_{\mathrm{i}}=$ fat retention coefficient in ricotta, $0.725=$ average fat content $(\%)$ in whey (Teixeira and Fonseca, 2008), $\mathrm{RP}_{\mathrm{i}}=$ protein retention coefficient in ricotta, 0.82 $=$ average protein content $(\%)$ in whey (Teixeira and Fonseca, 2008) and 69.6 = average moisture content (\%) in ricotta (Esper et al., 2007).

The values of variables obtained from the literature (Barbosa et al., 2009; Canziani and Guimarães, 2003; Andreatta et al., 2009; Modler, 1988; Aquino et al., 2009; Esper et al., 2007) for each equation are shown in Table 5.

\section{Maximum raw milk price}

Raw milk costs were not considered in the calculations of unit direct costs. Indirect costs were shared based on the volume of raw milk used for each product in each scenario. The weighted average indirect costs per L of raw milk and shadow prices of milk components were used to establish the maximum price of a $\mathrm{L}$ of raw milk in US\$ that the dairy could pay to its suppliers using the following equation:

$\$_{\mathrm{RM}}=\mathrm{S}_{\mathrm{RM}}+1.03 *\left(\mathrm{~S}_{\mathrm{P}} * \% \mathrm{P}_{\mathrm{S}}+\mathrm{S}_{\mathrm{C}} * \% \mathrm{C}_{\mathrm{S}}+\mathrm{S}_{\mathrm{F}} * \% \mathrm{~F}_{\mathrm{S}}\right) / 100-\mathrm{C}_{\mathrm{I}^{\prime}}$

where: $\$_{\mathrm{RM}}=$ maximum price of $\mathrm{L}$ of raw milk $\left(\mathrm{US} \$ \mathrm{~L}^{-1}\right)$, $\mathrm{S}_{\mathrm{RM}}=$ shadow price of one $\mathrm{L}$ of raw milk $\left(\mathrm{US} \$ \mathrm{~L}^{-1}\right), 1.03$ $=$ average density $\left(\mathrm{kg} \mathrm{L}^{-1}\right)$ of raw milk, $\mathrm{S}_{\mathrm{P}}=$ shadow price of one $\mathrm{kg}$ of protein in raw milk (US $\left.\$ \mathrm{~kg}^{-1}\right), \% \mathrm{P}_{\mathrm{S}}=$ average protein content $(\%)$ of raw milk from the supplier, $\mathrm{S}_{\mathrm{C}}=$ shadow price of one $\mathrm{kg}$ of casein in raw milk (US\$ $\left.\mathrm{kg}^{-1}\right), \% \mathrm{C}_{\mathrm{S}}=$ average casein content $(\%)$ of raw milk from the supplier, $\mathrm{S}_{\mathrm{F}}=$ shadow price of one $\mathrm{kg}$ of fat in raw milk (US\$ $\left.\mathrm{kg}^{-1}\right), \% \mathrm{~F}_{\mathrm{S}}=$ average fat content $(\%)$ in raw milk from the supplier and $\mathrm{C}_{\mathrm{I}}=$ weighted average indirect costs per L of processed raw milk (US\$ $\left.\mathrm{L}^{-1}\right)$.

\section{Pricing of different types of raw milk from two dairy farmers}

We calculated and compared the raw milk prices from two producers (Producer 1 and Producer 2) of the 50 dairy farmers that supplied raw milk with distinct quantities and qualities to the dairy plant using the Equation 16 in both scenarios. Producer 1 supplied raw milk with fat, protein and casein contents $(\%)$ greater than Producer 2, though at a lower volume.

\section{Earnings Before Taxes, Interest, Depreciation and Amortization (EBTIDA)}

We calculated and compared the actual and optimal Earnings Before Taxes, Interest, Depreciation and Amortization (EBTIDA) of the dairy under both scenarios using Equations 17 and 18 as follows:

$$
\begin{aligned}
& \text { EBTIDA }_{\text {actualj }}=\mathrm{TCM}_{\text {actualj }}-\mathrm{V}_{\mathrm{RM} 1 \mathrm{j}} *\left(\$_{\mathrm{RM} 1 \text { actualj }}+\mathrm{C}_{\mathrm{I}}\right)- \\
& \mathrm{V}_{\mathrm{RM} 50 \mathrm{j}} *\left(\$_{\text {RM50actualj }}+\mathrm{C}_{\mathrm{I}}\right)
\end{aligned}
$$

Table 5 - Values of variables for each of the equations of quantity, volume and yield of raw materials, intermediate and final dairy products in daily scenarios of high (January) and low (July) raw milk supplies.

\begin{tabular}{lccccccccccc}
\hline Variables $^{*}$ & $\mathrm{XM}$ & $\mathrm{YM}$ & $\mathrm{MS}$ & $\mathrm{MC}$ & $\mathrm{MB}$ & $\mathrm{MF}$ & $\mathrm{PB}$ & $\mathrm{SP}$ & $\mathrm{RC}$ & $\mathrm{C} 40_{X}$ & $\mathrm{C} 40_{Y}$ \\
\hline RF & - & - & $0.88^{\mathrm{a}}$ & $0.86^{\mathrm{b}}$ & $0.86^{\mathrm{b}}$ & $0.85^{\mathrm{c}}$ & $0.73^{\mathrm{b}}$ & $0.73^{\mathrm{b}}$ & $0.97^{\mathrm{d}}$ & - & - \\
$\mathrm{PC}$ & - & - & $0.32^{\mathrm{a}}$ & $0.36^{\mathrm{b}}$ & $0.36^{\mathrm{b}}$ & $0.13^{\mathrm{c}}$ & $0.53^{\mathrm{b}}$ & $0.53^{\mathrm{b}}$ & - & - & - \\
$\mathrm{W}$ & - & - & $49.85^{\mathrm{a}}$ & $46.00^{\mathrm{b}}$ & $46.00^{\mathrm{b}}$ & $61.31^{\mathrm{e}}$ & $39.00^{\mathrm{b}}$ & $39.00^{\mathrm{b}}$ & $69.60^{\mathrm{f}}$ & - & - \\
RP & - & - & - & - & - & - & - & - & $0.99^{\mathrm{d}}$ & - & - \\
\hline
\end{tabular}

${ }^{*} \mathrm{XM}=$ brand $\mathrm{X}$ cooled standardized pasteurized milk; $\mathrm{YM}=$ brand $\mathrm{Y}$ cooled standardized pasteurized milk; $\mathrm{MS}=$ Minas Standard cheese; $\mathrm{MC}=\mathrm{Mozzarella}$ cheese; MB: Mozzarella Ball cheese; MF = Minas Fresh cheese; $\mathrm{PB}=$ Provolone Ball cheese; $\mathrm{SP}=$ Spicy Provolone cheese and RC = Ricotta cheese; $\mathrm{C}^{2} 0_{x}$ and $\mathrm{C} 40_{\mathrm{y}}=$ milk cream with $40 \%$ of fat from the standardization of $\mathrm{XM}$ and $\mathrm{YM}$ milk, respectively. RF = coefficient of fat retention in cheese; $\mathrm{PC}=$ casein loss of raw milk; $\mathrm{W}=$ average content (\%) of moisture in cheese and RP = coefficient of protein retention in cheese; Source: (Barbosa et al., 2009), b(Canziani and Guimarães, 2003), c(Andreatta et al., 2009), d(Modler, 1988), e(Aquino et al., 2009) and f(Esper et al., 2007). 


$$
\begin{aligned}
& \text { EBTIDA }_{\text {optimalj }}=\mathrm{TCM}_{\text {optimalj }}-\left(\$_{\text {RM1optimalj }} * \mathrm{~V}_{\mathrm{RM} 1 \mathrm{j}+}\right. \\
& \left.\$_{\text {RM50optimalj }} * \mathrm{~V}_{\mathrm{RM} 50 \mathrm{j}}\right)
\end{aligned}
$$

where: EBTIDA $_{\text {actualj }}=$ actual earnings before taxes, interest, depreciation and amortization (US\$) under scenario ' $\mathrm{j}$ ', TCM $\mathrm{Tctualj}_{\text {a }}=$ actual total contribution unit (US\$) under scenario ' $\mathrm{j}$ ', $\mathrm{V}_{\mathrm{RM} 1 \mathrm{j}}=$ volume $(\mathrm{L})$ of $\mathrm{RM} 1$ available under scenario ' $\mathrm{j}$ ', $\$_{\text {RM1actualj }}=$ actual price of one $\mathrm{L}$ of RM1 (US\$ $L^{-1}$ ) in scenario ' $j^{\prime}, C_{I}=$ weighted average indirect costs per $\mathrm{L}$ of processed raw milk (US\$ $\left.\mathrm{L}^{-1}\right), \mathrm{V}_{\mathrm{RM} 50 \mathrm{j}}$ $=$ volume $(\mathrm{L})$ of RM50 available in scenario ' $\mathrm{j}$ ', $\$_{\text {RM50actualj }}$ $=$ actual price of a L of RM50 (US\$ $\mathrm{L}^{-1}$ ) under scenario

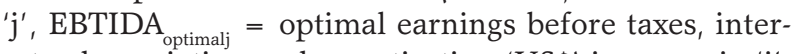
ests, depreciation and amortization (US\$) in scenario ' $\mathrm{j}$ ', $\mathrm{TCM}_{\text {optimalj }}=$ optimal total contribution unit (US\$) under scenario ' $\mathrm{j}^{\prime}, \$_{\mathrm{RM} 1 \text { optimalj }}=$ optimal price of one L of RM1 (US\$ $\mathrm{L}^{-1}$ ) in scenario ' $\mathrm{j}$ ' and $\$_{\text {RM50optimalj }}=$ optimal price of a L of RM50 (US $\$ \mathrm{~L}^{-1}$ ) in scenario ' $\mathrm{j}$ '. Interest, taxes, depreciation and amortization were not included.

\section{Results and discussion}

Dairy product mixes and total contribution margins

The optimal solutions, as well as the actual mixes, were obtained for models processed in accordance with the constraints of both scenarios (Table 6). Under the scenario of high raw milk supply (January), great differences were seen between the optimal and actual mixes. In the actual mix, the raw milk was used for processing eight dairy products (XM, YM, MC, MF, PB, SP, RC and $\mathrm{C} 40$ ), while in the optimal mix, all the 10 dairy products would be processed to meet minimum demand. The differences between the shares of these products in the optimal and actual mixes ranged from 0.43 (RC) to 3228.15 $\mathrm{kg}(\mathrm{YM})$ in absolute values, and from $8 \%(\mathrm{RC})$ to $100 \%$ (MS and MB) in relative values. The cooled pasteurized milk had a higher share in both mixes. As expected, the TCM was higher in the optimal solution than in the actual one by US $\$ 2021.10$ (34 \%).

Under the scenario of low raw milk supply (July), despite all dairy products participating in both mixes, there were also differences between the optimal and actual mixes. The differences in the shares of XM (4\%), YM (12\%), PB (1\%), SP (0 \%) and RC (6\%) between the optimal and actual mixes were very small. The greatest differences in share between the two mixes were found in MS (97\%), MC (33\%), MB (68\%) and MF (69 \%). The cooled pasteurized milk had a higher share in both mixes, as well as under the January scenario. As expected, TCM was higher in the optimal solution than in the actual one by US $\$ 224.08(5 \%)$. The TCM in both mixes were higher in January due to the greater availability of components from two raw milk types for processing dairy products during this period, demonstrating the importance of raw milk volume and quality to the TCM of dairies.

Compared to XM and YM products, the processed volumes indicated in the optimal solution were higher in January due to the greater availability of RM1 and RM50 in this period, respectively. Because of this difference in availability of RM50 for processing YM and cheeses, the relative YM participation in the optimal mix of July was lower than that of January. On the other hand, the XM participation in the optimal mix of July was higher than that of January, because there was little difference in RM1 supplied to produce XM between both scenarios. Therefore, XM production decreased slightly compared to that of YM.

Although the optimal mix of January showed greater XM and YM production, a higher volume of C40 was produced in July due to higher fat content in both raw milk types in this scenario. Interestingly, C40 gen-

Table 6 - Combinations and contribution margins of optimal and actual mixes of dairy products produced in daily scenarios of high (January) and

\begin{tabular}{|c|c|c|c|c|c|c|c|c|c|c|c|}
\hline \multirow{2}{*}{ Dairy products ${ }^{1}$} & \multicolumn{11}{|c|}{ High raw milk supply (January) } \\
\hline & XM & YM & MS & MC & MB & MF & PB & $\mathrm{SP}$ & $\mathrm{RC}$ & C40 & Total Sum \\
\hline Optimal mix, L² or kg & 1180.37 & 6193.12 & 1.00 & 127.00 & 1.00 & 105.60 & 6.00 & 6.00 & 5.00 & 28.79 & 7653.88 \\
\hline Actual mix, $\mathrm{L}^{2}$ or kg & 711.55 & 2964.97 & 0.00 & 380.44 & 0.00 & 71.58 & 6.74 & 6.74 & 5.43 & 55.74 & 4203.19 \\
\hline Optimal mix, \% & 15.42 & 80.91 & 0.01 & 1.66 & 0.01 & 1.38 & 0.08 & 0.08 & 0.07 & 0.38 & 100.00 \\
\hline Actual mix, \% & 16.93 & 70.54 & 0.00 & 9.05 & 0.00 & 1.70 & 0.16 & 0.16 & 0.13 & 1.33 & 100.00 \\
\hline TCM ${ }^{3}$ optimal, US\$ ${ }^{4}$ & 1095.26 & 5376.83 & 6.44 & 687.39 & 7.17 & 577.07 & 45.82 & 47.88 & 12.15 & 34.20 & 7890.61 \\
\hline \multirow[t]{2}{*}{$\mathrm{TCM}^{3}$ actual, US\$ $\$$} & 660.25 & 2574.17 & 0.00 & 2059.13 & 0.00 & 391.16 & 51.47 & 53.79 & 13.21 & 66.22 & 5869.51 \\
\hline & \multicolumn{11}{|c|}{ Low raw milk supply (July) } \\
\hline Optimal mix, $\mathrm{L}^{2}$ or kg & 1094.64 & 2396.83 & 1.00 & 127.00 & 1.00 & 110.60 & 1.00 & 1.00 & 10.00 & 61.30 & 3804.38 \\
\hline Actual mix, L² or kg & 1054.32 & 2721.03 & 30.61 & 84.77 & 0.32 & 34.25 & 1.01 & 1.00 & 9.36 & 55.74 & 3992.43 \\
\hline Optimal mix, \% & 28.77 & 63.00 & 0.03 & 3.34 & 0.03 & 2.91 & 0.03 & 0.03 & 0.26 & 1.61 & 100.00 \\
\hline Actual mix, \% & 26.41 & 68.15 & 0.77 & 2.12 & 0.01 & 0.86 & 0.03 & 0.03 & 0.23 & 1.40 & 100.00 \\
\hline $\mathrm{TCM}^{3}$ optimal, US\$${ }^{4}$ & 1015.71 & 2080.92 & 6.44 & 687.39 & 7.17 & 604.39 & 7.64 & 7.98 & 24.30 & 72.83 & 4514.77 \\
\hline $\mathrm{TCM}^{3}$ actual, US\$ ${ }^{4}$ & 978.30 & 2362.38 & 197.02 & 458.84 & 2.31 & 187.17 & 7.70 & 7.98 & 22.75 & 66.22 & 4290.69 \\
\hline
\end{tabular}
low (July) raw milk supplies.

${ }^{1} \mathrm{XM}=$ brand X cooled standardized pasteurized milk; YM = brand Y cooled standardized pasteurized milk; MS = Minas Standard cheese; MC = Mozzarella Common cheese; MB = Mozzarella Ball cheese; MF = Minas Fresh cheese; PB = Provolone Ball cheese; SP = Spicy Provolone cheese; RC = Ricotta cheese and C40 = milk cream with $40 \%$ of fat from the standardization of XM and YM; ${ }^{2} 1 \mathrm{~L}=1 \mathrm{dm}^{3}=10^{-3} \mathrm{~m}^{3} ;{ }^{3} \mathrm{TCM}=$ Total contribution margin of dairy products and ${ }^{4} \mathrm{US} \$ 1.000=\mathrm{R} \$$ 1.675 (Brazil, 2013); Source: elaborated by the authors based on data from the dairy and the Clinic of Milk Lab. 
eration in the actual mix for both months was identical. Consequently, the relative $\mathrm{C} 40$ share in both mixes rose in July.

The four products (SP, $\mathrm{PB}, \mathrm{MB}$ and $\mathrm{MS}$ ) with higher UCM, plus the RC and C40 products, showed the smallest shares in the mixes under both scenarios. This is explained by the result of dividing UCM by the required amount of raw material (raw milk and its components) for processing one $\mathrm{L}$ or $\mathrm{kg}$ of each product (Table 7).

Although the UCM of three (XM, YM and MF) of the four highest participating products in the optimal mixes of both scenarios are within the six lowest for the dairy product line, these products, except for C40, presented the highest UCM per unit of raw material (US\$ $\mathrm{L}^{-1}$ or US $\$ \mathrm{~kg}^{-1}$ ) under both scenarios (Table 7). Thus, the manufacturing and marketing of products with greater UCM by limiting factor must be prioritized to optimize the use of critical raw materials as limiting factors. This means that producing more products with lower UCM can be more profitable than producing a product with higher UCM in smaller quantities. Therefore, the relationship between UCM and amounts of required raw materials per unit of product was decisive in defining the optimal mixes. The third largest share of the MC product in optimal mixes of both scenarios was due to the need to meet the minimum demands of this product because its UCM per unit of raw material was the lowest.

The UCM per unit of raw materials was higher for the cheese line in July due to a lower amount of raw material required for processing a single unit of milk product. However, for XM and YM milks, it occurred otherwise, because both types of raw milk had higher levels of solid components, including fat, in July than in January. Therefore, the raw milk loss in the standardization of fat XM and YM milks in July was larger.

The XM milk would be included in the optimal mixes regardless of the relationship between UCM and the requirement for raw material, because it does not compete with any other milk product. Its raw material, the raw milk from a single supplier, is exclusively used for its processing. On the other hand, the other dairy products are processed with raw milk from the other 50 milk suppliers. Therefore, these products compete for raw materials to participate in the mixes.

In the optimal mixes of both scenarios, the YM milk participates only because of its restriction of MF cheese production by the packager, since this product was given preference for participation in the mixes due to its higher UCM per the required quantity of raw material.

Under both scenarios, the quantities of dairy products MS, MC, MB, PB, SP and RC determined by the optimal solution, were equal to the quantities defined by the minimum demand. These products were included in the production mix just to meet the minimum demand constraints. If the minimum demand constraints do not exist, these products would not be included in the production mix as they have UCM per unit of raw material lower than those of the other participants in the dairy production mix (Table 7). As all types of cheese competed for packaging, this was the limiting factor in $\mathrm{MF}$ cheese production in the optimal mixes (Table 8).

The C40 creams were included in the mixes because they are intermediate products obtained from the standardization of XM and YM pasteurized milks. In dairies, whose production processes a wide variety of products that may generate intermediate products, such as cream and whey, which are raw materials for other products, optimization techniques have already been efficiently deployed (Banaszewska et al., 2013; Geary et al., 2010a; Geary et al., 2010b; Geary et al., 2012; Guan and Philpott, 2011; Milad and Faezeh, 2012). This optimization relies heavily on the production process, together with marketing and management of raw materials - raw milk which is considered a constraint, because of its irregular availability throughout the year given the seasonality of its production (Banaszewska et al., 2013; Brockington et al., 1992; Geary et al., 2012; Roma et al., 2009).

Table 7 - Relationship between the UCM and the required quantities of raw materials (raw milk volume and its components) of dairy products in daily scenarios of high (January) and low (July) raw milk supplies.

\begin{tabular}{|c|c|c|c|c|c|c|c|c|c|}
\hline \multirow{2}{*}{ Resources" } & \multicolumn{9}{|c|}{ High raw milk supply (January) } \\
\hline & XM & YM & MS & MC & $\mathrm{MB}$ & MF & PB & SP & $\mathrm{RC}$ \\
\hline Raw milk, US\$ $\mathrm{L}^{-1^{*+}}$ & 0.92 & 0.87 & 0.79 & 0.61 & 0.80 & 0.89 & 0.67 & 0.70 & 0.62 \\
\hline Protein, US\$ kg-1* & 27.27 & 26.32 & 24.10 & 18.46 & 24.47 & 27.09 & 20.31 & 21.22 & 18.90 \\
\hline Casein, US\$ kg ${ }^{-1 *}$ & 34.93 & 33.60 & 30.76 & 23.57 & 31.24 & 34.59 & 25.93 & 27.10 & 24.13 \\
\hline \multirow[t]{2}{*}{ Fat, US\$ kg .1 $^{-{ }^{*}}$} & 30.93 & 28.94 & 24.69 & 18.92 & 25.07 & 27.76 & 20.81 & 21.74 & 19.36 \\
\hline & \multicolumn{9}{|c|}{ Low raw milk supply (July) } \\
\hline Raw milk, US\$ $\mathrm{L}^{-1 *+}$ & 0.91 & 0.86 & 0.86 & 0.66 & 0.87 & 0.96 & 0.72 & 0.75 & 0.67 \\
\hline Protein, US\$ kg ${ }^{-1 *}$ & 25.85 & 25.22 & 25.26 & 19.35 & 25.65 & 28.29 & 21.25 & 22.20 & 19.83 \\
\hline Casein, US\$ kg ${ }^{-1 *}$ & 33.27 & 32.88 & 32.92 & 25.23 & 33.43 & 36.88 & 27.70 & 28.94 & 25.85 \\
\hline Fat, US\$ $\mathrm{kg}^{-1{ }^{*}}$ & 30.93 & 28.94 & 23.49 & 18.00 & 23.85 & 26.31 & 19.76 & 20.65 & 18.44 \\
\hline
\end{tabular}

\#XM = brand X cooled standardized pasteurized milk; YM = brand Y cooled standardized pasteurized milk; MS = Minas Standard cheese; MC = Mozzarella Common cheese; MB = Mozzarella Ball cheese; MF = Minas Fresh cheese; PB = Provolone Ball cheese; SP = Spicy Provolone cheese; RC = Ricotta cheese; ${ }^{*}$ US\$ $1.000=$ R\$ 1.675 (Brazil, 2013) and $+1 \mathrm{~L}=1 \mathrm{dm}^{3}=10^{-3} \mathrm{~m}^{3}$; Source: elaborated by the authors based on data from the dairy and the Clinic of Milk Lab. 
All dairy products produced were deemed to be sold because there were no records of product returns in either January or July. This fact is due to increasing urban demand for dairy products in Brazil where $80 \%$ of the fluid milk, condensed milk and cream are sold in supermarkets. In the state of São Paulo the retail sector is even more important, reaching $85 \%$ of sales of these products (Novo et al., 2010). Conditional cash transfer programs implemented by the Brazilian Federal Government have contributed to this increasing demand for dairy products. More than $54 \%$ of households included in the program increased consumption of dairy products such as cheese, yogurt, curd and chocolates made with milk (Lignani et al., 2010).

\section{Shadow prices of limiting resources}

In January, casein in RM1 and RM50 raw milks and packaging were the limiting operating resources, because their supply was fully deployed in the processing of dairy products. Thus, they were also the only resources to show shadow prices. In July, limiting operating resources that presented shadow prices were casein of RM1 raw milk, the liter of RM50 raw milk and packaging (Table 8).

As the fat from both raw milk types was not fully used, it did not show a shadow price, because it did not limit the processing of dairy products. However, if the dairy had fat-based products, such as butter, cream cheese or milk cream in its line of dairy products, fat from milk RM50 may have a shadow value. Other studies (Banks, 2004; Cash et al., 2005; Davis et al., 2012; FAO, 2013; Gruebele, 1978; Hill et al., 2002; Sandrou and Arvanitoyannis, 2000; Zandstra et al., 2001) also demonstrated fat devaluation relative to other raw milk components due to changes in consumers' eating habits.

Table 8 - Balances and shadow prices of resources of the dairy in daily scenarios of high (January) and low (July) raw milk supplies.

\begin{tabular}{|c|c|c|c|c|}
\hline \multirow{2}{*}{$\begin{array}{l}\text { Scenarios } \\
\text { Resources }\end{array}$} & \multicolumn{2}{|c|}{$\begin{array}{c}\text { High raw milk } \\
\text { supply (January) }\end{array}$} & \multicolumn{2}{|c|}{$\begin{array}{l}\text { Low raw milk } \\
\text { supply (July) }\end{array}$} \\
\hline & Balance & Shadow price & Balance & Shadow price \\
\hline & & US\$\# & & US\$\# \\
\hline Raw milk $1, L^{*}$ & 16.38 & 0.00 & 6.53 & 0.00 \\
\hline Raw milk fat $1, \mathrm{~kg}$ & 5.30 & 0.00 & 11.00 & 0.00 \\
\hline Raw milk protein $1, \mathrm{~kg}$ & 0.70 & 0.00 & 0.04 & 0.00 \\
\hline Raw milk casein $1, \mathrm{~kg}$ & 0.00 & 34.61 & 0.00 & 34.00 \\
\hline Raw milk $50, L^{*}$ & 60.75 & 0.00 & 0.00 & 0.88 \\
\hline Raw milk fat 50, kg & 14.92 & 0.00 & 16.37 & 0.00 \\
\hline Raw milk protein $50, \mathrm{~kg}$ & 1.24 & 0.00 & 0.62 & 0.00 \\
\hline Raw milk casein $50, \mathrm{~kg}$ & 0.00 & 33.44 & 0.67 & 0.00 \\
\hline Pasteurizer, h & 4.38 & 0.00 & 5.20 & 0.00 \\
\hline Standardized, h & 4.82 & 0.00 & 5.59 & 0.00 \\
\hline Bagging, $\mathrm{h}$ & 3.34 & 0.00 & 4.89 & 0.00 \\
\hline Packager, h & 0.00 & 7.16 & 0.00 & 18.99 \\
\hline Labor force, $\mathrm{h}$ & 12.76 & 0.00 & 16.78 & 0.00 \\
\hline
\end{tabular}

\#US\$ $1.000=\mathrm{R} \$ 1.675$ (Brazil, 2013) and * $1 \mathrm{~L}=1 \mathrm{dm}^{3}=10^{-3} \mathrm{~m}^{3}$ Source elaborated by the author based on data obtained from the dairy and the Milk Clinic Lab.
The value of milk fat may decrease as a result of lower demand for higher-fat foods, such as butter, to the detriment of increased consumer preference for lower-fat foods, such as "dairy spreads" and other low-fat dairy products, rich in protein (Banks, 2004; Cash et al., 2005; Davis et al., 2012; FAO, 2013; Gruebele, 1978; Hill et al., 2002; Sandrou and Arvanitoyannis, 2000; Zandstra et al., 2001).

A study on consumer demand for dairy products in the region of Boston, USA, indicates that there is a preference for fat-containing conventional milk, especially in households with children under 15 years of age, and the preference increases with an increased number of children in that age group. On the other hand, the higher the household income, the greater the preference for special types of milk, such as organic milk, lactose-free milk and, above all, low-fat milk (Lopez and Lopez, 2009).

In California, for example, the change of consumers' preference from whole milk to skimmed milk was one of the reasons to establish the payment of milk components. This trend in consumers' eating habits leads the dairy industry to invest in increased production of protein-rich dairy products, causing appreciation of this nutrient in relation to other solid milk components, and the payment system should reflect this valuation (Gruebele, 1978, 1979).

\section{Raw milk prices and EBTIDA}

The shadow prices of components of both raw milk types, the TCM and fixed and indirect costs of an

Table 9 - Total contribution margins, average weighted indirect costs per liter of raw milk, maximum, actual and intermediates prices of the two types of raw milk and EBITDA from the dairy under the daily scenarios of high (January) and low (July) raw milk supplies.

\begin{tabular}{|c|c|c|}
\hline Scenarios & $\begin{array}{l}\text { High raw milk } \\
\text { supply (January) }\end{array}$ & $\begin{array}{l}\text { Low raw milk } \\
\text { supply (July) }\end{array}$ \\
\hline \multicolumn{3}{|l|}{ Results with maximum raw milk prices } \\
\hline Optimal total contribution margin, US\$ & 7890.21 & 4514.77 \\
\hline Maximum raw milk price $1, \mathrm{US} \$ \mathrm{~L}^{-1 \#}$ & 0.83 & 0.78 \\
\hline Maximum raw milk price $50, \mathrm{US} \$ \mathrm{~L}^{-1 \#}$ & 0.78 & 0.73 \\
\hline Optimal indirect cost of raw milk, US\$ $\mathrm{L}^{-1 \#}$ & 0.08 & 0.14 \\
\hline EBITDA* (maximum price), US\$ & 448.65 & 579.66 \\
\hline \multicolumn{3}{|l|}{ Results with actual raw milk prices } \\
\hline Actual total contribution margin, US\$ & 5869.39 & 4290.69 \\
\hline \multirow{3}{*}{$\begin{array}{l}\text { Actual raw milk price, US\$ } \mathrm{L}^{-1 \#} \\
\text { Actual average indirect raw milk cost, } \\
\text { US\$ } \mathrm{L}^{-1 \#} \\
\text { EBITDA* (actual price), US\$ }^{*}\end{array}$} & 0.39 & 0.48 \\
\hline & 0.10 & 0.15 \\
\hline & 1316.43 & 971.37 \\
\hline \multicolumn{3}{|l|}{ Results with intermediate raw milk prices } \\
\hline \multirow{2}{*}{$\begin{array}{l}\text { Optimal total contribution margin, US\$ } \\
\text { Intermediate average price of both types } \\
\text { of raw milk, US\$ } \mathrm{L}^{-1 \#}\end{array}$} & 7890.21 & 4514.77 \\
\hline & 0.60 & 0.52 \\
\hline Optimal indirect cost of raw milk, US\$ $\mathrm{L}^{-1 \#}$ & 0.08 & 0.14 \\
\hline EBITDA* (intermediate price), US\$ & 1316.43 & 971.37 \\
\hline
\end{tabular}

${ }^{\# 1} \mathrm{~L}=1 \mathrm{dm}^{3}=10^{-3} \mathrm{~m}^{3}$ and ${ }^{*}$ EBITDA $=$ Earnings Before Taxes, Interest, Depreciation and Amortization; US\$1.000 = R\$ 1.675 (Brazil, 2013); Source: elaborated by the author based on data obtained from the dairy and the Milk Clinic Lab. 
L of raw milk allowed for the calculation of prices for a $\mathrm{L}$ of both raw milk types as well as optimal and actual EBITDA of the dairy (Table 9).

The TCM was higher in January due to the greater volume of milk available for the production of dairy products. This result was expected because January and July are the peak and off-season periods, respectively, in southeastern Brazil. Therefore, the indirect and fixed costs for each L of raw milk processed were lower in January, because the higher the volume of raw milk available for processing by the dairy, the greater the dilution of fixed and indirect costs for the volume of processed milk. Under both scenarios, as expected, the optimal TCM was higher than the actual one due to a better allocation of resources for products with higher UCM per unit of active limiting feature.

Applying the average indirect costs of a litter of raw milk and shadow prices of components from the two types of raw milk to Equation 16, formulated for calculating the maximum price of $1 \mathrm{~L}$ of raw milk, we obtained maximum raw milk prices higher than those actually realized by the dairy. The maximum price of RM1 raw milk was higher than the RM50 raw milk maximum price under both scenarios. Prices calculated for both raw milk types were higher in January, contrary to reality where the highest prices are realized during the off-season (July scenario). This occurred as the UCM per quantity of limiting resource required per dairy product was higher in the January scenario.

Each dairy determines its own criteria for bonuses or penalties depending on the quality of the milk (TBC and SCC, besides solid milk compounds). Law No. 12669 has been in effect since 19 June 2012, which obliges dairies to inform the price of a $\mathrm{L}$ of raw milk to suppliers by the $25^{\text {th }}$ day of the month preceding milk purchase (Brazil, 2012). Every month, Conseleite (the Brazilian Joint Council of Producers and Milk Processors) calculates the reference price for standard raw milk depending on the mix of dairy products, yield of industrial products, production costs and raw milk quality (Canziani and Guimarães, 2003). It is more advantageous for the dairy to remunerate the raw milk supplier for a raw material that improves production efficiency and yield (Geary et al., 2010b). However, there is no Brazilian program for pricing a kg of solid milk components, as proposed in this study.

We obtained the optimal and actual EBITDA through the application of the values from Table 9 to Equations 17 and 18. The actual daily EBITDA was higher than the optimal daily EBITDA under both scenarios because actual prices were lower than the maximum prices calculated for a L of both raw milk types. Still, the results of the optimal daily EBITDA in both scenarios demonstrate that it is possible to make a profit even when paying more for raw materials.

However, the dairy can get the same actual EBITDAs from January and July by producing optimal mixes for both scenarios without the need for extra purchase cost of raw material. For this, it is necessary to calculate
Table 10 - Volumes, compositions, maximum prices and total revenue of two raw milk suppliers of the dairy under daily scenarios of high (January) and low (July) raw milk supplies.

\begin{tabular}{lrrrrr}
\hline Scenarios & \multicolumn{2}{c}{$\begin{array}{c}\text { High raw milk } \\
\text { supply (January) }\end{array}$} & & \multicolumn{2}{c}{$\begin{array}{c}\text { Low raw milk } \\
\text { supply (July) }\end{array}$} \\
\cline { 1 - 2 } \cline { 5 - 6 } Suppliers & Producer & Producer 2 & & Producer 1 & Producer 2 \\
\hline Raw milk volume, L\# & 44.26 & 156.59 & & 22.83 & 109.98 \\
Fat, \% & 3.49 & 2.36 & & 4.69 & 2.38 \\
Protein, \% & 3.85 & 2.98 & & 3.54 & 3.51 \\
Casein, \% & 2.95 & 2.43 & & 2.83 & 2.20 \\
Maximum raw & 0.94 & 0.76 & & 0.73 & 0.73 \\
\hline milkprice, US\$
\end{tabular}

$\# 1 \mathrm{~L}=1 \mathrm{dm}^{3}=10^{-3} \mathrm{~m}^{3}$ and ${ }^{*} \mathrm{US} \$ 1.000=\mathrm{R} \$ 1.675$ (Brazil, 2013); Source: elaborated by the author based on data obtained from the dairy and the Milk Clinic Lab.

the intermediate average price of one L of raw milk that the dairy could pay its suppliers in January and July. Equating equation 18 of optimal EBITDA to the values obtained in the actual EBITDAs for January (US\$ 1316.43) and July (US\$ 971.37), respectively, and isolating the response variables (intermediate average price of one L of milk raw of both scenarios) of the equations, it was possible to determine their values. The price of raw milk would amount to US\$ $0.60 \mathrm{~L}^{-1}$ and US\$ $0.52 \mathrm{~L}^{-1}$ in January and July, respectively, to get the same actual EBITDAs with optimal mixes without additional acquisition costs of raw materials.

\section{Raw milk prices from two dairy farmers}

We calculated maximum prices of RM50 from two suppliers of the dairy producing raw milk in different quantities and qualities under both scenarios (Table 10). The maximum price per liter of raw milk to be paid by dairy to both producers was higher in January. Although Producer 2 supplied higher raw milk volume to the dairy than Producer 1, the latter produced raw milk with higher solid contents, including casein, whose shadow price was US\$ $33.44 \mathrm{~kg}^{-1}$, consequently, its raw milk had a higher price under both scenarios. In July, the maximum price per liter of raw milk was the same for both producers because its value was determined by the volume shadow price of RM50 (US\$ $0.88 \mathrm{~L}^{-1}$ ), less the indirect cost (US\$ $0.14 \mathrm{~L}^{-1}$ raw milk) under this scenario.

\section{Conclusions}

Linear programming is a useful tool for dairies for production planning, for maximizing TCM which should be incorporated into raw milk pricing and consider shadow prices of milk limiting components. The relationship between UCM and the required amount of raw material per product unit and resource availability are crucial to defining the mix of dairy products and the TCM of the dairy. Raw milk pricing in the proposed model remunerates the dairy farmer based on the raw milk components produced. The dairy can increase its EBITDA and remunerate better its suppliers based on raw milk qual- 
ity with better planning of its product mix. Although the data used are from a Brazilian dairy that produces regional cheeses, the optimization model developed in linear programming can be applied to any dairy with appropriate adaptations throughout the world. In addition, the portfolio of dairy products herein is not restricted to regional cheeses; it also includes Mozzarella, Provolone and Ricotta, which are produced worldwide.

\section{Acknowledgments}

The authors wish to thank the CAPES agency /Coordination for the Improvement of Higher Level Personnel) for granting a $\mathrm{PhD}$ scholarship to the first author and the Milk Clinic Lab (Laboratory of the Animal Science Department of the College of Agriculture "Luiz de Queiroz" of University of São Paulo accredited by Brazilian Milk Quality Analysis Laboratory Network) for providing data on raw milk composition purchased by the dairy.

\section{References}

Anderson, D.L.; Mistry, V.V.; Brandsma, R.L.; Baldwin, K.A. 1993. Reduced fat cheddar cheese from condensed milk. 1 . Manufacture, composition, and ripening. Journal of Dairy Science 76: 2832-2844.

Andreatta, E.; Santos, M.V.; Mussarelli, C.; Marques, M.C.; Gigante, M.L. 2009. Quality of minas frescal cheese prepared from milk with different somatic cell counts. Pesquisa Agropecuária Brasileira 44: 320-326.

Applied Economic Research Institute [IPEA]. 2013. Brazil Central Bank. Balance of Payments Bulletin. Commercial exchange rate for sale: real (R\$) / US dollar (US\$) - 2011 annual average = Banco Central do Brasil. Boletim de Balanço de Pagamentos. Taxa de câmbio comercial para venda: real (R\$) / dólar americano (US\$) - média anual de 2011. Available at: http:// www.ipeadata.gov.br/ [Accessed Mar 26, 2013] (in Portuguese).

Aquino, A.A.; Peixoto Junior, K.D.C.; Gigante, M.L.; Rennó, F.P.; Prada e Silva, L.F.; Santos, M.V. 2009. Effect of increasing levels of urea in the diet of dairy cows on the composition and yield of minas frescal cheesemaking frescal $=$ Efeito de níveis crescentes de uréia na dieta de vacas leiteiras sobre a composição e rendimento de fabricação de queijos minas frescal. Brazilian Journal of Veterinary Research and Animal Science 46: 7 (in Portuguese).

Banaszewska, A.; Cruijssen, F.; Vorst, J. van der; Claassen, G.; Kampman, J. 2013. A comprehensive dairy valorization model. Journal of Dairy Science 96: 761-779.

Banks, J.M. 2004. The technology of low-fat cheese manufacture. International Journal of Dairy Technology 57: 199-207.

Barbosa, J.B.; Talma, S.V.; Batista, C.S.; Martins, M.L.; Pinto, C.L.O. 2009. Evaluation of yield of minas frescal cheese production, minas standard and mozzarella made from milk inoculated with Pseudomonas fluorescens = Avaliação de rendimento da produção dos queijos minas frescal, minas padrão e mussarela fabricados com leite inoculado com Pseudomonas fluorescens. Revista do Instituto de Laticínios "Cândido Tostes" 64: 8 (in Portuguese).
Blowey, R.W.; Edmondson, P. 2010. Mastitis Control in Dairy Herds. 2ed. CABI, Wallingford, UK.

Botaro, B.G.; Gameiro, A.H.; Santos, M.V. 2013. Quality based payment program and milk quality in dairy cooperatives of southern Brazil: an econometric analysis. Scientia Agricola 70: 21-26.

Brockington, N.R.; Veil, J.M.; Zoccal, R. 1992. Herd dynamics and management strategies for small-scale milk production systems in southeast Brazil. Agricultural Systems 39: 201-225.

Canziani, J.R.; Guimarães, V.D.A. 2003. Instruction Manual Conseleite - Paraná = Manual de Instruções do Conseleite Paraná. Centro de Documentação, Informações Técnicas e Biblioteca do SENAR, Curitiba, PR, Brazil (in Portuguese).

Cash, S.B.; Wang, C.; Goddard, E.W. 2005. Dairy products and consumer demand for health foods. Advances in Dairy Technology 17: 67-80.

Dantzig, G.B. 1998. Linear Programming and Extensions. Princeton University Press, Princeton, NJ, USA.

Davis, C.G.; Dong, D.; Blayney, D.; Yen, S.T.; Stillman, R. 2012. U.S. fluid milk demand: a disaggregated approach. International Food and Agribusiness Management Review 15: 25-50.

Emmons, D.B.; Modler, H.W. 2010. Invited review: a commentary on predictive cheese yield formulas. Journal of Dairy Science 93: 5517-5537.

Esper, L.M.R.; Bonets, P.A.; Kuaye, A.Y. 2007. Evaluation of physico-chemical ricotta marketed in Campinas-SP and accuracy of nutrition information stated on the labels. Revista do Instituto Adolfo Lutz 3: 6 (in Portuguese, with abstract in English).

Federative Republic of Brazil. 2012. Law 12.669, June 19, 2012 $=$ Lei 12.669 de 19 de junho de 2012. Diário Oficial da União, Brasília, v. 149, n. 118, 20 de junho de 2012. p. 1. (in Portuguese).

Food and Agriculture Organization [FAO]. 2013. Milk and Dairy Products in Human Nutrition. FAO, Rome, Italy.

Geary, U.; Lopez-Villalobos, N.; Garrick, D.; Shalloo, L. 2010 b. Development and application of a processing model for the Irish dairy industry. Journal of Dairy Science 93: 5091-5100.

Geary, U.; Lopez-Villalobos, N.; Garrick, D.; Shalloo, L. 2012. An analysis of the implications of a change to the seasonal milk supply profile in the Irish dairy industry utilizing a seasonal processing sector model. Journal of Agricultural Science 150: 389-407.

Geary, U.; Shalloo, L.; Lopez, N. 2010a. Development of a dairy processing sector model for the Irish dairy industry. Advances in Animal Biosciences 1: 335-335.

Gruebele, J.W. 1978. Effects of removing the dairy price-support program. Illinois Agricultural Economics 18: 30-38.

Gruebele, J.W. 1979. The California experience in component pricing. Journal of Dairy Science 62: 1368-1373.

Guan, Z.; Philpott, A. 2011. A multistage stochastic programming model for the New Zealand dairy industry. International Journal of Production Economics 134: 289-299.

Hill, D.S.; Knox, J.; Hamilton, J.; Parr, H.; Stringer, M. 2002. Reduced-fat foods: the shopper's viewpoint. International Journal of Consumer Studies 26: 44-57.

Kerrigan, G.L.; Norback, J.P. 1986. Linear-programming in the allocation of milk resources for cheese making. Journal of Dairy Science 69: 1432-1440. 
Lignani, J.B.; Sichieri, R.; Burlandy, L.; Salles-Costa, R. 2010. Changes in food consumption among the Programa Bolsa Família participant families in Brazil. Public Health Nutrition 14: 785-792.

Lopez, E.; Lopez, R.A. 2009. Demand for differentiated milk products: implications for price competition. Agribusiness 25: 453-465.

McCarl, B.A.; Meeraus, A.; Eijk, P. van der; Bussieck, M.; Dirkse, S.; Steacy, P.; Nelissen, F. 2013. McCarl GAMS User Guide. GAMS Development Corporation, Washington, DC, USA.

Melilli, C.; Lynch, J.M.; Carpino, S.; Barbano, D.M.; Licitra, G.; Cappa, A. 2002. An empirical method for prediction of cheese yield. Journal of Dairy Science 85: 2699-2704.

Milad, G.A.; Faezeh, M. 2012. Considering different types of constraints for production planning for a dairy product: a case study. The Journal of Commerce 4: 4 .

Modler, H.W. 1988. Development of a continuous process for the production of ricotta cheese. Journal of Dairy Science 71: 20032009.

Novo, A.; Jansen, K.; Slingerland, M.; Giller, K. 2010. Biofuel, dairy production and beef in Brazil: competing claims on land use in São Paulo state. The Journal of Peasant Studies 37: 769792 .
Roma, L.C.; Montoya, J.F.G.; Martins, T.T.; Cassoli, L.D.; Machado, P.F. 2009. Seasonability of protein and other milk components related with quality payment program. Arquivo Brasileiro de Medicina Veterinaria e Zootecnia 61: 1411-1418 (in Portuguese, with abstract in English).

Sandrou, D.K.; Arvanitoyannis, I.S. 2000. Low-fat/calorie foods: current state and perspectives. Critical Reviews in Food Science and Nutrition 40: 427-447.

Sharma, S. 2006. Introductory Operation Research. Discovery Publishing House, Grand Rapids, MI, USA.

Teixeira, L.V.; Fonseca, L.M. 2008. Physical-chemical profile of whey from Mozzarella and Minas-Standard cheesemaking from various regions of the state of Minas Gerais. Arquivo Brasileiro de Medicina Veterinária e Zootecnia 60: 8 (in Portuguese, with abstract in English).

Zandstra, E.H.; Graaf, C.; Staveren, W.A. van. 2001. Influence of health and taste attitudes on comsumption of low- and high-fat foods. Food Quality and Preference 12: 75-82. 